\title{
Physicochemical Parameters, Phytochemical Composition and Antioxidant Activity of the Algarvian Avocado (Persea americana Mill.)
}

\author{
Ana F. Vinha ${ }^{1,2}$, Joana Moreira ${ }^{1} \&$ Sérgio V. P. Barreira ${ }^{1}$ \\ ${ }^{1}$ FCS/UFP-Faculdade de Ciências da Saúde, Universidade Fernando Pessoa (FCS-UFP), Rua Carlos da Maia, \\ Porto, Portugal \\ ${ }^{2}$ REQUIMTE/Departamento de Ciências Químicas, Laboratório de Bromatologia e Hidrologia, Faculdade de \\ Farmácia da Universidade do Porto, Rua de Jorge Viterbo Ferreira, Porto, Portugal \\ Correspondence: Ana F. Vinha, Faculdade de Ciências da Saúde, Universidade Fernando Pessoa (FCS-UFP), Rua \\ Carlos da Maia, Porto, Portugal. Tel: 352-225-074-630. E-mail: acvinha@ufp.edu.pt
}

Received: September 2, 2013 Accepted: September 22, 2013 Online Published: November 15, 2013

doi:10.5539/jas.v5n12p100

URL: http://dx.doi.org/10.5539/jas.v5n12p100

\begin{abstract}
The physical, chemical and nutritional properties of Persea americana fruits variety 'Hass' produced in the Algarve region were studied. Edible and non-edible parts of the fruits (pulp, seeds and peel) were compared considering their possible contribution to improve the sustainability of the food and pharmaceutical industries. The nutritional contents evaluated were moisture, ash, proteins, fat, total soluble solids and acidity. It were also evaluated the contents of bioactive compounds (phenolics, flavonoids, carotenoids, ascorbic acid and vitamin E) and their influence in the antioxidant activity exhibited by the fruit material. The results of the analysis demonstrated that the Algarvian avocado has physical and chemical characteristics comparable or superior to avocados from other growing regions around the world namely, Mexico and California. With regard to the contents of bioactive compounds, the pulp of the Algarvian avocado proved to be rich in carotenoids $(0.815 \pm 0.201 \mathrm{mg} / 100 \mathrm{~g})$, phenolic compounds $(410.2 \pm 69.0 \mathrm{mg} / 100 \mathrm{~g})$ and flavonoids $(21.9 \pm 1.0 \mathrm{mg} / 100 \mathrm{~g})$. The skin was superior to the pulp in the contents of all these compounds with $2.585 \pm 0.117 \mathrm{mg} / 100 \mathrm{~g}$ of carotenoids, $679.0 \pm 117.0 \mathrm{mg} / 100 \mathrm{~g}$ of total phenolics and $44.3 \pm 3.1 \mathrm{mg} / 100 \mathrm{~g}$ of flavonoids. The seed, in turn, was the part of the fruit with the highest total phenolic content $(704.0 \pm 130.0 \mathrm{mg} / 100 \mathrm{~g})$ and flavonoids $(47.97 \pm 2.69 \mathrm{mg} / 100 \mathrm{~g})$. Regarding the concentration of vitamins $\mathrm{C}$ and $\mathrm{E}$, the highest values were found in the pulp $(5.36 \pm 1.77 \mathrm{mg} / 100 \mathrm{~g}$ of vitamin E) and skin $(4.1 \pm 2.7 \mathrm{mg} / 100 \mathrm{~g}$ of vitamin C). The extracts obtained from the seeds demonstrated higher in vitro $\mathrm{DPPH}^{\bullet}$ assay antioxidant activity $(43 \%)$ than those obtained from the skin $(35 \%)$ and the fruit pulp (23\%). The contents of carotenoids, phenolic compounds and flavonoids found in the non-edible parts of the Algarvian avocado demonstrated that these byproducts could be an interesting inexpensive raw material for the food and cosmetic industries.
\end{abstract}

Keywords: Persea americana Mill., Algarvian avocado, food byproducts, bioactive compounds, antioxidant activity, edaphoclimatic conditions

\section{Introduction}

The Persea americana Mill. tree belongs to the family Lauraceae, genus Persea and is a plant native of Central America. Apart from its use as food the avocado is traditionally utilized for various medicinal purposes including as hypotensive, hypoglycemic and anti-viral, and is applied for the treatment of ulcers and cardiovascular diseases (Anita et al., 2005; Nayak et al., 2008; Raharjo et al., 2008; Anaka et al., 2009; Kosińska et al., 2012). To the avocados are equally attributed analgesic and anti-inflammatory properties (Adeyemi et al., 2002) and the avocado pulp is also used in various dermatological formulations namely, emulsions for the treatment of dry skin, protective agents against ultraviolet radiation, and anti-aging agents (Korać \& Khambholja, 2011). Given the variety of uses that are assigned to ethnobotanical species Persea americana several studies have been conducted in order to unveil their biological activity (Gomez-Flores et al., 2008; Yasir et al., 2010; Pahua-Ramos et al., 2012). For example the characterization of phenolic components and antioxidant activity of hydroethanolic extracts of the avocado skin and seed revealed a predominance of compounds belonging to the group of 
flavonoids, proanthocyanidins, and hydrocinnamic acids (Kosińska et al., 2012). Phenolics and flavonoids are bioactive compounds that have been related with a decrement of different deteriorative processes in the human body owing to their ability to reduce the formation and to scavange free radicals (Hidalgo et al., 2010). Rodríguez-Carpena and coworkers (2011) ascribed the high antioxidant activity exhibited by avocado extracts in various in vitro assays to these phenolic compounds. Chia and Dykes (2010) studied the essential oils of avocado and were able to demonstrate the antimicrobial activity of the skin and seeds of three different varieties of avocado ('Hass', 'Fuerte' and 'Shepard'). Other studies revealed that the avocado contains other classes of bioactive compounds with antioxidant properties and that are equally beneficial to Human metabolism, such as mineral constituents (phosphorus, magnesium and potassium), hydro and liposoluble vitamins (vitamin E, B, C and $\beta$-carotene, or provitamin A) (Honarbakhsh \& Schachter, 2009; USDA, 2011). Given all the above, prominence has been given in certain countries, to public information about the avocado and its health promoting properties. An independent Australian organization, "The Heart Foundation" certified the fruit as healthy food for the heart and this certification with its appropriate logo is already used in advertising. The Californian Avocado Commission, has also driven efforts to publicize the fruit as health promoter, including conjoint publications with the American Dietetic Association, American Heart Association, and more recently, some press releases. For all the reasons above, the avocado is gaining worldwide recognition as healthy food and, consequently, a significant economic value. Hence, quite naturally, the avocado culture has attracted the interest of European farmers and, currently, it is already possible to find avocado orchards spread across Spain, Italy, Greece and Portugal. Regarding cultivars produced, 'Hass' and 'Fuerte' dominate the international market (Rodríguez-Carpena et al., 2011). In Portugal these fruits are being cultivated in the south (Algarve), where the soil and climatic conditions are more favorable. The cultivated area at present does not exceed 750 acres but it is rapidly expanding, as more and more farmers recognize the potential of this crop (Freire, 2012). The avocado tree is one of the most productive plants per unit of cultivated area. The Algarve region has a temperate Mediterranean climate, characterized by mild short winters and long, hot and dry summers. The soils of this region are mostly litholic not humic of sandstone, stoneware of Silves or similar. Given that the edaphoclimatic conditions play a fundamental role in plant metabolism and by this route in the chemical makeup of fruits, one of the objectives of this study was to evaluate the chemical and antioxidant composition of the Algarvian 'Hass' avocado and compare their content of phytochemicals with those of the same variety of fruit produced elsewhere. This is pioneering study, since, to the best of our knowledge, this is the first scientific characterization of the Portuguese avocado fruit. The non-edible parts of the fruit (skin and seed) were also studied in order to assess their potential use as cheap source of bioactive compounds for the food, pharmaceutical and dermocosmetic industries. The exploitation of non-edible parts of the fruits is an emerging trend which may prove to be very profitable in the near future. Firstly because it entails an important reduction in the production of waste, secondly, because the non-edible parts of some fruits, can concentrate high levels of valuable bioactive compounds, particularly natural antioxidants (Vinha et al., 2013).

\section{Materials and Methods}

\subsection{Sample Collection and Preparation}

All the avocado fruits, variety 'Hass' used in the present study came from an orchard located in the Faro area (Latitude: $37.019^{\circ}$, Longitude: $-7.926^{\circ}$ ). The fruits, a total of 100 at the onset of ripening, were randomly collected and selected by their firmness, absence of mechanical damage and visible decay. Immediately after harvest the fruits were cleaned and prepared according to the requirements of the intended analysis. They were cut open to obtain their edible and non-edible portions (pulp, peel, and seeds, respectively) and stored at $4^{\circ} \mathrm{C}$. Six replicates of each sample were selected and analyzed. All analyzes were carried out over a period of time not exceeding two weeks after harvest.

\subsection{Standards and Reagents}

2,6-dichlorophenol-indophenol (Tillmans reagent), glacial acetic acid, meta-phosphoric acid, DL- $\alpha$-tocopherol acetate sodium carbonate, $\beta$-carotene, petroleum ether, ascorbic acid, sodium phosphate, aluminium chloride and 2,2-diphenyl-1-picrylhydrazyl radical ( $\mathrm{DPPH}^{\circ}$ ) were obtained from Sigma-Aldrich (St. Louis, MO, USA). Methanol, the Folin-Ciocalteu reagent, sodium hydroxide, sulphuric acid, and gallic acid were purchased from Panreac Química S.L.U. (Barcelona, Spain). All aqueous solutions were prepared with Milli Q filtered water (resistivity $>18 \mathrm{M} \Omega . \mathrm{cm}$ ) (Millipore, Bedford, MA).

\subsection{Proximate Composition Analysis}

Moisture, titratable acidity (TA), total soluble solids (TSS) were evaluated as quality fruit indices. The ash, total protein and total fat contents were also analyzed. A gravimetric assay was performed to evaluate the 
physiological weight loss of the avocado fractions (pulp, peel, and seeds). It was calculated by the difference between initial and final weight. A porcelain capsule containing $5 \mathrm{~g}$ of each fresh avocado fraction was placed in a stove (WTC binder Klasse 2.0, Tuttlingen, Germany) at $105 \pm 1^{\circ} \mathrm{C}$, followed by regular weighing up to a constant weight. Results were expressed in water percentage (\%). TA was determined by titrating $5 \mathrm{ml}$ of avocado aqueous extract with $0.1 \mathrm{M} \mathrm{NaOH}$, using phenolphthalein $(1 \%)$ as indicator. Results were expressed as grams of tartaric acid per $100 \mathrm{~g}$ of sample, according to the methodology described by the Association of Official Analytical Chemists (2005). The TSS were quantified using a hand digital refractometer Leica Abbe Mark II (Leica, Buffalo, NY, USA) and expressed as ${ }^{\circ}$ Brix.

As with all food analysis procedures it is crucial to carefully select a sample whose composition represents that of the food being analyzed and to ensure that its composition does not change significantly prior to analysis. The following methods (AOAC, 2005) were used to determine protein, fat and ash content in stored avocado pulp, peel and seed samples: micro Kjeldahl for protein ( $\mathrm{N} x$ 5.7) (method 960.52) (Glass Model Pyrex-1); incineration at $550^{\circ} \mathrm{C}$ for ash (method 923.03) (PCSIR-Lhr); defatting in a Soxhlet apparatus (J.P.Selecta-Spain) with 2:1 (v/v) chloroform/methanol for lipids (method 920.39C). All experiments were repeated in sextuplicate and the values are presented as mean $( \pm \mathrm{SD})$.

\subsection{Bioactive Compounds Quantification}

\subsubsection{Extraction and Analysis of Ascorbic Acid}

Avocado fruit fractions (5 g) were dissolved in a mixture of $200 \mathrm{ml}$ of water, $5 \mathrm{ml}$ of metaphosphoric acid (30\%) and $20 \mathrm{ml}$ glacial acetic acid. The mixture was titrated with Tillmans reagent. Ascorbic acid (expressed as $\mathrm{mg} / 100 \mathrm{~g}$ (on a FW - fresh weight basis)) was quantified using an analytical validated method published in a previously work (Vinha et al., 2012).

\subsubsection{Colorimetric Determination of Tocopheryl Acetate (Vitamin E)}

The determination of the vitamin E content in the different constituents of Algarvian avocado fruit followed the procedure described by Amin (2001). From a standard solution of $\alpha$-tocopherol acetate in $100 \mathrm{ml}$ of methanol, several dilute solutions were prepared by taking 10,25,50,100,200,400 $\mu$ l aliquots of the stock solution and placing them in $25 \mathrm{ml}$ calibrated flasks.

$\alpha$-tocopheryl acetate was converted into $\alpha$-tocopherol by transesterification. Standards were prepared by taking $10,25,50,100,250$ and $500 \mu \mathrm{l}$ portions of stock solution in $25 \mathrm{ml}$ calibrated flasks, adding a drop of sulphuric acid, to catalyze the reaction, and $20 \mathrm{ml}$ of methanol to each, and heating at $90^{\circ} \mathrm{C}$ in a water-bath for $90 \mathrm{~min}$; within this period, the flask contents were reduced almost to dryness. The end-product of transesterification was dissolved in $15 \mathrm{ml}$ of methanol, and $5.0 \mathrm{ml}$ of $\mathrm{NaOH}(0.2 \mathrm{M})$ were added. The absorbance at $526 \mathrm{~nm}$ was measured after $10 \mathrm{~min}$ of heating in a water-bath at $90 \pm 2^{\circ} \mathrm{C}$. The experiments were performed in sextuplicate for each avocado fruit fraction (pulp, peel, and seed).

\subsubsection{Total Carotenoids Assay}

Total carotenoids were extracted according to Akin et al. (2008) with some minor modifications. Briefly, five grams of sample were homogenized using a high-speed homogenizer, at $5000 \mathrm{rpm}$ for 30 minutes (Heidolph, Diax 900, Germany) and then transferred to a separating funnel for extraction with $100 \mathrm{ml}$ of methanol/petroleum ether $(1: 9, \mathrm{v} / \mathrm{v})$. The petroleum ether layer was then filtrated through sodium sulphate, transferred to a $100 \mathrm{ml}$ volumetric flask and dissolved with petroleum ether. Finally, total carotenoid content was measured spectrophotometrically (Hitachi UV-2800 spectrophotometer) at $450 \mathrm{~nm}$ by using an extinction coefficient of 2592. Results were expressed as $\beta$-carotene equivalents (milligrams per $100 \mathrm{~g}$ of $\mathrm{FW}$ ).

\subsubsection{Total Polyphenolic Content Assay}

Total phenolics were determined according to the improved Folin-Ciocalteu method (Zieliski \& Kozowska, 2000). Briefly, $5 \mathrm{~g}$ of fresh avocado fruit fractions were homogenized by using a homogenizer (model F.60, Falc Instruments, Italy) in water $(100 \mathrm{ml}) \mathrm{kept}$ at $40^{\circ} \mathrm{C}$ for one hour and then filtered. The avocado fruit extracts were then resuspended in water and the supernatant $(0.5 \mathrm{ml})$ was mixed with $0.5 \mathrm{ml}$ of Folin-Ciocalteu's solution. The solution was homogenized for 3 minutes and $1 \mathrm{ml}$ of saturated $\mathrm{Na}_{2} \mathrm{CO}_{3}$ was added. The solution was then incubated for 1 hour in the dark to obtain color development, through the reduction of phosphomolybdic and phosphotungstic acids in alkaline medium. The absorbance readings were measured at $720 \mathrm{~nm}$ with an UV-VIS spectrophotometer (Shimadzu UV-2100), using gallic acid (GA) as standard. Total phenol content was expressed as milligrams of GA equivalent (GAE) per 100 grams of fresh fruit weight (mg GAE $/ 100 \mathrm{~g}^{-1} \mathrm{FW}$ ). 


\subsubsection{Total Flavonoids Content}

Flavonoid contents in the aqueous extracts of the pulp, peel, and seeds of avocado fruits were determined using a method described by Soares et al. (2013) with slight modifications. Aliquots of $1 \mathrm{ml}$ of extract solution were mixed with $4 \mathrm{ml}$ of water and $300 \mu \mathrm{L}$ sodium nitrate $25 \%$. After 5 min incubation at room temperature it was added $300 \mu \mathrm{l}$ of $\mathrm{AlCl}_{3}$ reagent $(10 \%)$, and left to react for one minute before adding $2 \mathrm{ml}$ of sodium hydroxide and $2.4 \mathrm{ml}$ of water. The absorbance was recorded at $510 \mathrm{~nm}$ in a BioTek Synergy HT microplate reader (GENS5). The flavonoid contents were express in milligrams per 100 grams of FW.

\section{5 $\mathrm{DPPH}^{\bullet}$ Radical-Scavenging Activity}

Pulp, peel and seeds of avocado aqueous extracts $(300 \mu \mathrm{l})$ were mixed with $2.7 \mathrm{ml}$ of an ethanolic solution containing $\mathrm{DPPH}^{\bullet}\left(2,2\right.$-diphenyl-1-picrylhydrazyl radical) in a concentration of $6 \times 10^{-5} \mathrm{M}$. The mixture was shaken vigorously and left to stand in the dark until stable absorbance readings at $517 \mathrm{~nm}$. The radical scavenging activity (RSA) was calculated as a percentage of $\mathrm{DPPH}^{*}$ discoloration using the equation: \% RSA = [(ADPPH $\left.\left.{ }^{\bullet}-\mathrm{AS}\right) / \mathrm{ADPPH}^{*}\right] \times 100$, where AS represents the absorbance of the sample solution extract with $\mathrm{DPPH}^{\circ}$. and $\mathrm{ADPPH}^{\bullet}$ is the absorbance of the $\mathrm{DPPH}^{*}$ solution.

\subsection{Statistical Analysis}

A completely randomized design was used, with six replications. Statistical analysis was performed using SPSS v. 21 (IBM Corp., Armonk, NY, USA). Data of all chemical analysis were expressed as mean \pm standard deviation. The independent samples T-test or Analysis of Variance (ANOVA) were used to assess the statistical differences among means followed, in the case of ANOVA, by Tukey's HSD post-hoc test for multiple comparisons. Pearson correlation tests were used to ascertain the existence of linear relationships between the contents of bioactive compounds and antioxidant activity. The level of significance for all hypothesis tests $(p)$ was 0.05 .

\section{Results and Discussion}

As previously referred, the objectives of this study were to characterize the Algarvian avocado in terms of food and potential source of bioactive compounds for the food and cosmetics industries. The results obtained for the fruit physicochemical parameters are presented in Table 1.

Table 1. Physicochemical parameters of the different fractions of the Algarvian avocado variety 'Hass'. Moisture, proteins, ash and fat are expressed in percentage. The Total Soluble Solids in ${ }^{\circ}$ Brix and the acidity in $\mathrm{mg}$ of tartaric acid equivalents $/ 100 \mathrm{~g} \mathrm{FW}$

\begin{tabular}{lccc}
\hline & Fraction of the Algarvian avocado var. 'Hass' \\
\hline Parameter $^{* *}$ & Pulp $^{*}$ & Skin $^{*}$ & Seeds $^{*}$ \\
\hline Moisture (\%) & $70.83 \pm 3.53^{\mathrm{a}}$ & $69.13 \pm 2.58^{\mathrm{b}}$ & $54.45 \pm 2.33^{\mathrm{c}}$ \\
Ash (\%) & $1.77 \pm 0.16^{\mathrm{a}}$ & $1.50 \pm 0.08^{\mathrm{b}}$ & $1.29 \pm 0.03^{\mathrm{c}}$ \\
Proteins (\%) & $1.82 \pm 0.07^{\mathrm{a}}$ & $1.91 \pm 0.08^{\mathrm{a}}$ & $2.19 \pm 0.16^{\mathrm{b}}$ \\
Fat (\%) & $43.5 \pm 4.62^{\mathrm{a}}$ & $2.20 \pm 1.65^{\mathrm{b}}$ & $14.7 \pm 0.32^{\mathrm{b}}$ \\
Total Soluble Solids ( ${ }^{\mathrm{a}}$ Brix) & $6.68 \pm 1.02^{\mathrm{a}}$ & $3.01 \pm 2.03^{\mathrm{b}}$ & $3.54 \pm 1.97^{\mathrm{b}}$ \\
Acidity & $1.07 \pm 0.02^{\mathrm{a}}$ & $2.05 \pm 0.24^{\mathrm{b}}$ & $2.67 \pm 0.17^{\mathrm{b}}$ \\
\hline
\end{tabular}

As shown in Table 1, *Values represented as mean \pm standard deviation obtained from six measurements; **A letter is used to express the result of the comparison between the different fractions. Different letters indicate significant statistical differences (95\% significance).

The moisture content is one of the most important indices evaluated in foods, especially fruits. It is a good indicator of their economic value because it reflects solid contents and serves to assess its perishability. The results indicate that the Algarvian avocado pulp has a higher water content $(70.83 \%)$, followed the skin $(69.13 \%)$ and seed $(54.45 \%)$. The fat and ash quantified in pulp were significantly superior to those found in the skin. The seed was the part of the fruit that had higher amounts of total protein $(2.19 \%)$ and lowest ash content $(1.29 \%)$, nevertheless, relative to its fat content, showed higher percentages compared to those found on the exocarp. According to Hernández-Muñoz et al. (2006) the total acidity is a measure of the organic acid content. The predominant acid found in avocados is tartaric acid although, theoreticaly, every species capable of donating a proton, including fatty acids, also contribute to the total acidity of the fruit (Omar et al., 2012). Acidity and soluble solids content are the common quality attributes that are associated with the maturity index of 
agricultural products, especially fruits. The total acidity tends to decrease during the ripening period as a result of the breathing process or conversion into sugars. In the period of maturation of the fruit there is an increase in metabolic activity and organic acids are, par excellence, a source of energy reserve of the fruit through the Krebs cycle. In the case of the mature Algarvian avocado, the seed has higher acidity than the skin or pulp. The acidity of the pulp was found to be superior to that exhibited by 'Hass' avocados of American origin $(0.04 \pm 0.01 \%$ citric acid) (Arias et al., 2012). In any case Algarvian 'Hass' avocados may be considered a non acidic fruit.

Among the various components of fruit, the total soluble solids (i.e., the percentage of solids that are dissolved in the matrix of the food) in ${ }^{\circ}$ Brix, have a primary role in their quality due to the influence on thermophysical, chemical and biological properties. It is also a parameter which tends to increase with the progress of ripening due to the biosynthesis of the plant and degradation of polysaccharides. As expected, given that this physico-chemical parameter represents one of the best ways to evaluate the degree of sweetness of the fruit, and the fruit pulp is the only edible part of the avocado, the total soluble solids are higher in the pulp. This parameter follows a trend that is opposite to acidity. Nevertheless the content of soluble solids, although superior to those reported for 'Hass' avocados of American origin (5.1 $\pm 0.1^{\circ} \mathrm{Brix}$ ) (Arias et al., 2012), can be considered low, favoring the consumption of the Algarvian avocado in natura. Superior values of TSS have been reported for 'Hass' avocados from New Zeland ( $\sim 9^{\circ}$ Brix) (Burdon et al., 2007).

The characteristics of a fruit depend on the cultivar, the edaphoclimatic conditions of the region of provenance, ripeness and storage conditions (Ahmed et al., 2010). Tango et al. (2004) studied 24 varieties of avocado, and found levels for moisture and fat in the pulp of 'Hass' variety fruits of $57.3 \%$ and $31.1 \%$, respectively. These values are significantly lower than those found in the Algarvian avocado studied here. Regarding the avocado seeds, Olaeta et al. (2007) observed higher protein concentrations and ash, compared with those recorded in this study (3.18\% and $1.51 \%$, respectively). Lu et al. (2009) on the other hand, reported a value of $25 \%$ fat for the pulp of 'Hass' avocados cultivated in California. The Algarvian avocado develops mainly during the winter because during the rest of the year the orchards in the Algarve are subjected to water stress. This is an important factor to justify the results presented in Table 1 .

There is already evidence that the ingestion of fruits confers protection against human chronic diseases, neurological disorders and some types of cancer (Middleton et al., 2000; Pandey \& Rizvi, 2009; Hamid et al., 2010). These properties are assigned to the presence of significant levels of bioactive antioxidant compounds in fruits. For this reason, those molecules are attracting a growing interest from the scientific community. During the last decades, ample evidence of the benefits of avocado on health has been gathered (Yasir et al., 2010; Al-Dosari, 2011). This promoted their consumption, stimulating also the research about their pharmacological potential. The maturation of any fruit promotes an increase of bioactive compounds (Arancibia-Avila et al., 2008). Among the different secondary metabolites with antioxidant properties, phenolics, flavonoids and carotenoids are the most cited. The levels of these compounds, as well as those of the vitamins $\mathrm{C}$ and $\mathrm{E}$, found in the Algarvian avocado are presented in Table 2.

Table 2. Concentration of bioactive compounds present in different Algarvian avocado 'Hass' var. fruit fractions

\begin{tabular}{lccc}
\hline & \multicolumn{3}{c}{ Avocado fraction var. 'Hass' } \\
\hline Bioactive compound ${ }^{* *}$ & Pulp* $^{*}$ & Skin* & Seed $^{*}$ \\
\hline Total Phenolics & $410.2 \pm 69.0^{\mathrm{b}}$ & $679.0 \pm 117.0^{\mathrm{a}}$ & $704.0 \pm 130.0^{\mathrm{a}}$ \\
Flavonoids & $21.9 \pm 1.0^{\mathrm{b}}$ & $44.3 \pm 3.1^{\mathrm{a}}$ & $47.9 \pm 2.7^{\mathrm{a}}$ \\
Carotenoids & $0.815 \pm 0.201^{\mathrm{b}}$ & $2.585 \pm 0.117^{\mathrm{a}}$ & $0.966 \pm 0.164^{\mathrm{b}}$ \\
Vitamin C & $1.2 \pm 0.7^{\mathrm{c}}$ & $4.1 \pm 2.7^{\mathrm{a}}$ & $2.6 \pm 1.1^{\mathrm{a}, \mathrm{c}}$ \\
Vitamin E & $5.36 \pm 1.77^{\mathrm{a}}$ & $2.13 \pm 1.03^{\mathrm{b}}$ & $4.82 \pm 1.42^{\mathrm{a}}$ \\
\hline
\end{tabular}

As shown in Table 2, *Values represented as mean \pm standard deviation $\mathrm{mg} / 100 \mathrm{~g} \mathrm{FW}$ obtained from six measurements; **A letter is used to express the result of the comparison between the different fractions. Different letters indicate significant statistical differences (95\% significance).

The results reveal that is in the avocado seed that the highest levels of total phenolics and flavonoids are found. This agrees with the results reported for avocados cultivated in Mexico (Wang et al., 2010). The skin of the fruit had the highest carotenoid content, as expected, since this tissue is usually the fraction were these phytochemicals 
are concentrated. Recently a study proved that the composition of carotenoids and vitamin $\mathrm{E}$ in fruits is affected by several factors, including the degree of maturation and edaphoclimatic (Arancibia-Avila et al., 2008). Significant differences were found in the levels of carotenoids and vitamin $\mathrm{E}$ in 'Hass' avocados cultivated in four different Californian counties. It was concluded in the same study that the levels of carotenoids in the fruit pulp increased with the fat present in it and that the xanthophylls, in particular lutein and cryptoxanthin, were the predominant phytochemicals of this group, contributing approximately to $90 \%$ of the total carotenoids present in the 'Hass' avocado (Lu et al., 2005). When one compares the contents of bioactive compounds of the Algarvian fruit with those of other fruits produced in different parts of the globe, it may be noted that it has levels of phenolics in the pulp comparable to those found in Mexican 'Hass' avocados (4.9 $\pm 0.7 \mathrm{mg} \mathrm{GAE} / \mathrm{g} \mathrm{FW}$ ), inferior levels in the skin (12.6 $\pm 0.3 \mathrm{mg} \mathrm{GAE} / \mathrm{g} \mathrm{FW}$ ) and seeds (51.6 $\pm 1.6 \mathrm{mg} \mathrm{GAE} / \mathrm{g} \mathrm{FW}$ ) (Wang et al., 2010) while possessing comparable levels of flavonoids (26.36 QE/100 g FW) (Rodríguez-Carpena et al., 2011). The phenolic levels are also superior to those reported for the same fruit of Turkish provenance $(1.20 \pm 0.02 \mathrm{~g} / \mathrm{kg} \mathrm{FW}$ ) (Golukcu \& Ozdemir, 2010). The content of carotenoids is inferior to that found in Californian avocados $(42.2 \mu \mathrm{g} / \mathrm{g})(\mathrm{Lu}$ et al., 2009) and higher than that found in the corresponding fractions of Mexican 'Hass' avocados ((7.1 $\pm 0.6 \mu \mathrm{g} / \mathrm{g}$ (pulp), 15.2 $\pm 2.7 \mu \mathrm{g} / \mathrm{g}$ (skin), $6.3 \pm 0.9 \mu \mathrm{g} / \mathrm{g}$ (seed)) (Wang et al., 2010). Furthermore the Algarvian avocado has superior levels of carotenoids in the pulp than the 'Hass' avocados cultivated in New Zeland $(\sim 5.2 \mu \mathrm{g} / \mathrm{g})$, but inferior levels in the skin $(\sim 50 \mu \mathrm{g} / \mathrm{g})$ (Ashton et al., 2006). The mesocarp of the Algarvian avocado presented higher levels of vitamin $\mathrm{E}$, with a value that is statistically similar to that found in the seeds and above that found in the skin. The amount of this vitamin found in the pulp is comparable to that found in avocados grown in Brazil $(6.4 \mathrm{mg} / 100 \mathrm{~g}$ ) (Salgado et al., 2008) but superior to that of avocados from california $(27 \mu \mathrm{g} / \mathrm{g})(\mathrm{Lu}$ et al., 2009). The concentration of ascorbic acid is inferior to that reported for Californian avocados (17.3 mg/100g) (USDA, 2011).

Overall these results also demonstrate the potential of the non-edible parts of the avocado as a source of bioactive compounds. The skin of the Algarvian 'Hass' avocado contains 59\% of the carotenoids and the seeds $39 \%$ of total phenolic compounds and $42 \%$ of the flavonoids present in the fruit. Instead of being wasted as trash, fruit skin could constitute an inexpensive source of carotenoids in the dermocosmetic and food industries. Indeed the avocado is the fruit with the highest content of carotenoids in the exocarp. The carotenoid compounds are known to exert a protective action against cell damage caused by UV rays and pollution, which make them an essential ingredient of several dermatological formulations. Additionally the carotenoids, phenolics and flavonoids are known to prevent the risk of developing certain diseases related to age, such as premature aging, cancer and heart disease (Hidalgo et al., 2010). Both the skin and the seeds can also be harnessed as a source of these compounds to use as food additives (Ayala-Zavala et al., 2011). Remarkably the skin and seeds of avocado have higher levels of these compounds than those that exist in many other fruits and vegetables such as apple (Malus domestica), banana (Musa cavendish), tomatoes (Lycopersicum esculentum) or red cabbage (Brassica oleracae var. botrytis) just to name a few (Marinova et al., 2005; Lin \& Tang, 2007; Sulaiman et al., 2011; Vinha et al., 2013).

Consistent with the fact that they contain higher levels of bioactive antioxidant compounds, it was found that the avocado seeds also exhibit higher, and statistically different, values of in-vitro antioxidant activity (measured in this work through the ability to scavenge the 2,2-diphenyl-1-picrylhydrazyl radical (DPPH $\left.{ }^{\bullet}\right)$ ), Figure 1.

These results differ slightly from those reported in the literature since both Wang et al. (2010) and Rodríguez-Carpena et al. (2011) showed that the skin had superior antioxidant activity. In fact it turns out that both the skin and the seeds of avocado fruit are very rich in antioxidant compounds however the seed has greater content of flavonoids and phenolic compounds while the skin is richer in carotenoids. In general, the contribution of vitamin $C$ to the total antioxidant capacity of extracts varies with the type of fruit. In fact, vitamin $C$ due to its hydrophilic character is unique among the vitamins present in the avocado matrix, the majority of which, namely vitamins $\mathrm{A}, \mathrm{D}$ and $\mathrm{E}$, are all liposoluble. It is well known fact that the bioactive compounds do not all have the same antioxidant activity, thus, an increase in the level of a compound does not mean a proportional increase of antioxidant activity of the matrix (Sanjust et al., 2008). Furthermore for a complex extract, as the one in question, it is also necessary to take into account the synergistic or antagonistic effects among the various compounds present, which makes not only the antioxidant activity dependent of the concentration of each compound but also of the interaction between different compounds, antioxidants or not. Perhaps this is why when the concentration of the extracts doubles, the antioxidant activity exhibited by the pulp increases but remains unaltered in case to the skin and seeds. 


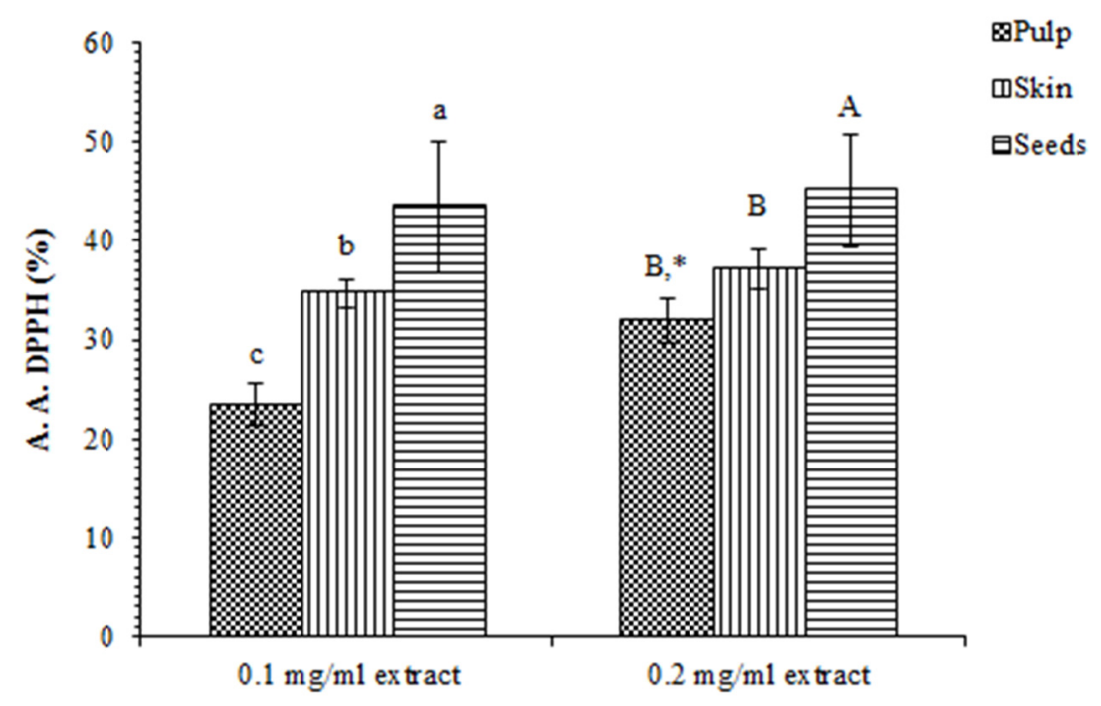

Figure 1. Antioxidant activity (A.A.) of aqueous extracts obtained from the various avocado fractions on 2,2-diphenyl-1-picrylhydrazyl radical ( $\left.\mathrm{DPPH}^{*}\right)$. The symbol "*" indicates the existence of significant statistical differences $(p<0.05)$ among the antioxidant activity exhibited by the two aqueous extracts of the same fraction. Identical letters signalize extracts that exhibit the same antioxidant activity

Most studies have demonstrated a linear correlation between total phenolic content and the antioxidant activity evaluated by different methodologies in fruits and vegetables (Mahattanatawee et al., 2006; Corral-Aguayo et al., 2008). Regression analyses were performed to correlate the antioxidant activity of avocado samples with the antioxidants quantified in the avocado tissues (Table 3).

Table 3. Correlation among the contents of bioactive compounds and $\mathrm{DPPH}^{\bullet}$ antioxidant activity

\begin{tabular}{|c|c|c|c|c|c|}
\hline \multirow{3}{*}{ Extract matrix } & Flavonoids & Phenolics & Carotenoids & Vitamin C & Vitamin E \\
\hline & $\mathrm{x}$ & $\mathrm{x}$ & $\mathrm{x}$ & $\mathrm{x}$ & $\mathrm{x}$ \\
\hline & $\mathrm{DPPH}^{\bullet}$ & $\mathrm{DPPH}^{\bullet}$ & $\mathrm{DPPH}^{\bullet}$ & $\mathrm{DPPH}^{\bullet}$ & $\mathrm{DPPH}^{\bullet}$ \\
\hline Pulp & -0.436 & -0.094 & -0.314 & 0.238 & 0.123 \\
\hline Skin & 0.678 & -0.430 & -0.132 & 0.220 & -0.880 \\
\hline Seeds & -0.506 & 0.715 & 0.703 & 0.011 & 0.641 \\
\hline
\end{tabular}

Considering all the different antioxidant compounds, a good correlation was found between total phenolic content determined by the Folin-Ciocalteu and flavonoids contents and DPPH radical scavenging capacity $(r=0.783)$ and $(\mathrm{r}=0.820)$, respectively. However, analyzing the fruit fractions separately, good positive correlations were only found for the contents of carotenoids, total phenolics and vitamin $\mathrm{E}$ and antioxidant activity exhibited by the seeds extracts and the contents of flavonoids in the case of the skin extracts.

\section{Conclusions}

Despite not being native of the region, the Algarvian avocado variety 'Hass' is a fruit with excellent physical and chemical characteristics, with moisture, protein, fat and ash comparable or superior to 'Hass' avocados from Mexico and California. Its levels of bioactive compounds are also comparable in the different constituent fractions of the fruit. Thus, for every $100 \mathrm{~g}$ of Algarvian avocado var. 'Hass', its edible portion (pulp) has, on average, $410.2 \pm 69.0 \mathrm{mg}$ of total phenolics, $21.9 \pm 1.0 \mathrm{mg}$ of flavonoids, $0.815 \pm 0.201 \mathrm{mg}$ of carotenoids, $1.2 \pm 0.7 \mathrm{mg}$ de vitamin $\mathrm{C}$ and $5.36 \pm 1.77 \mathrm{mg}$ of vitamin $\mathrm{E}$. The non-edible parts, i. e., the skin and seeds were found to have an average of $679.0 \pm 117.0 \mathrm{mg}$ total phenolics, $44.3 \pm 3.1 \mathrm{mg}$ of flavonoids, $2.585 \pm 0.117 \mathrm{mg}$ of carotenoids, $4.1 \pm 2.7$ $\mathrm{mg}$ of vitamin $\mathrm{C}$ and $2.13 \pm 1.03 \mathrm{mg}$ of vitamin $\mathrm{E}$ (skin) and $704.0 \pm 130.0 \mathrm{mg}$ of total phenolics, $47.97 \pm 2.69 \mathrm{mg}$ of flavonoids, $0.966 \pm 0.164 \mathrm{mg}$ of carotenoids, $2.6 \pm 1.1 \mathrm{mg}$ of vitamin $\mathrm{C}$ and $4.82 \pm 1.42 \mathrm{mg}$ of vitamin $\mathrm{E}$ (seeds). In accordance with the higher levels of bioactive compounds the extracts obtained from the seeds and skin of avocado 
presented higher antioxidant activity against the $\mathrm{DPPH}^{\circ}(43 \%$ and $35 \%$, respectively) compared to that exhibited by the pulp (only 23\%). The fact that the non-edible parts of the fruit (skin and seeds) contains such high levels of carotenoids, flavonoids and phenolics makes the idea of their exploitation, as a cheap source of these compounds in the food industry and dermo-cosmetics, very appealing. The mass of byproducts obtained as a result of processing tropical exotic crops, such as that of avocado, may approach or even exceed that of the corresponding edible part affecting the economics of growing of these crops.

\section{References}

Adeyemi, O. O., Okpo, S. O., \& Ogunti, O. O. (2002). Analgesic and anti-inflammatory effects of the aqueous extract of leaves of Persea americana Mill. (Lauraceae). Fitoterapia, 73(5), 375-380. http://dx.doi.org/10.3923/rjmp.2012.108.115

Ahmed, D. M., Yousef, A. R. M., \& Hassan, H. A. S. (2010). Relationship between electrical conductivity, softening and color of Fuerte avocado fruits during ripening. Agriculture Biology Journal North America, 1( 5), 878-885._http://dx.doi.org/10.5251/abjna.2010.1.5.878.885

Akin, E. B., Karabulut, I., \& Topcu, A. (2008). Some compositional properties of main Malatya apricot (Prunus armeniaca L.) varieties. Food Chemistry, 107, 939-948. http://dx.doi.org/10.1016/j.foodchem.2007.08.052

Al-Dosari, M. S. (2011). Hypolipidemic and antioxidant activities of avocado fruit pulp on high cholesterol fed diet in rats. African Journal Pharmacy Pharmacology, 5(12), 1475-1483. http://dx.doi.org/10.5897/AJPP11.239

Amin, A. S. (2001). Colorimetric determination of tocopheryl acetate (vitamin E) in pure form and in multivitamin capsules. European Journal Pharmaceutics Biopharmaceutics, 51(3), 267-272. http://dx.doi.org/10.1016/S0939-6411(00)00148-X

Anaka, O. N., Ozolua, R. I., \& Okpo, S. O. (2009). Effect of the aqueous seed extract of Persea americana Mill. (Lauraceae) on the blood pressure of spraguedawley rats. African Journal Pharmacy Pharmacology, 3(10), 485-490. Retrieved from http://www.academicjournals.org/ajpp

Anita, B. S., Okokon, J. E., \& Okon, P. A. (2005). Hypoglycemic activity of aqueous leaf extract of Persea americana Mill.. Indian Journal Pharmacology, 37(5), 325-326. Retrieved from http://www.bioline.org.br/pdf?ph05083

Arancibia-Avila, P., Toledo, F., Park, Y. S., Jung, S. T., Kang, S. G., Heo, B. G., Lee, S. H., Sajewicz, M., Kowalska, T., \& Gorinstein, S. (2008). Antioxidant properties of durian fruit as influenced by ripening. LWT - Food Science Technology, 41, 2118-2125. http://dx.doi.org/10.1016/j.lwt.2007.12.001

Arias, L. E. H., Gómez, J. H. P., \& Salazar, J. A. (2012). Application of the matrixes engineering on the development of minimally processed Hass avocado (Persea americana Mill) with additions of vitamin $\mathrm{C}$ and calcium. Revista Lasallista Investigación, 9(2), 44-54. Retrived from http://www.redalyc.org/articulo.oa?id=69525875016

Ashton, O. B. O., Wong, M., Mcghie, T. K., Vather, R., Wang, Y., Requejo-Jackman, C., ... Woolf, A. B. (2006). Pigments in avocado tissue and oil. Journal Agricultural Food Chemistry, 54, 10151-10158. http://dx.doi.org/10.1021/jf061809j

Association of Official Analytical Chemists (AOAC). (2005). Official methods of analysis of the Association of Official Analytical Chemists. 16 ed. Arlington. Retrived from http://www.aoac.org

Ayala-Zavala, J. F., Vega-Veja, V., Rosas-Domínguez, C., Palafox-Carlos, H., \& Villa-Rodriguez, J. A. (2011). Agro-industrial potential of exotic fruit byproducts as a source of food additives. Food Research International, 44, 1866-1874. http://dx.doi.org/10.1016/j.foodres.2011.02.021

Burdon, J., Lallu, N., Haynes, G., Francis, K., Boldingh, H., Pak, H. A., ... Dixon, J. G. M. (2007). Cutting preliminary studies of physiological and morphological indicators of potential poor quality in late season New Zealand 'Hass' avocados. Proceedings VI World Avocado Congress (Actas VI Congreso Mundial del Aguacate). Retrived from http://www.avocadosource.com/wac6/en/../4a-158.pd

Chia, T. W. R., \& Dykes, G. A. (2010). Antimicrobial activity of crude epicarp and seed extracts from mature avocado fruit (Persea americana) of three cultivars. Pharmaceutical Biology, 48(7), 753-756. http://dx.doi.org/10.3109/13880200903273922

Corral-Aguayo, R., Yahia, E. M., Carrillo-Lopez, A., \& Gonzalez-Aguilar, G. A. (2008). Correlation between some nutritional components and the total antioxidant capacity measured with six different assays in eight 
horticultural crops. Journal Agricultural Food Chemistry, 56(22), 10498-10504. http://dx.doi.org/10.1021/jf801983r

Freire, E. (2012). Abacate: uma nova aposta para o Algarve. Vida Rural, 1778, 30-32. Retrived from www.vidarural.pt/news.aspx?menuid=8\&eid=6479

Golukcu, M., \& Ozdemir, F. (2010). Changes in phenolic composition of avocado cultivars during harvesting time. Chemistry Natural Compounds, 46(1), 112-115._http://dx.doi.org/10.1007/s10600-010-9541-5.

Gomez-Flores, R., Arzate-Quintana, C., Quintanilla-Licea, R., Tamez-Guerra, P., Tamez-Guerra, R., Monreal-Cuevas, E., \& Rodríguez-Padilla, C. (2008). Antimicrobial activity of Persea americana Mill (Lauraceae) (avocado) and Gymnosperma glutinosum (Spreng.) Less (Asteraceae) leaf extracts and active fractions against mycobacterium tuberculosis. American-Eurasian Journal Scientific Research, 3(2), 188-194. Retrieved from http://www.idosi.org/aejsr/3(2)08/11.pdf

Hamid, A. A., Aiyelaagbe, O. O., Usman, L. A., Ameen, O. M., \& Lawal, A. (2010). Antioxidants: Its medicinal and pharmacological applications. African Journal Pure Applied Chemistry, 4(8), 142-151. Retrived from http://www.academicjournals.org/.../Hamid\%20et\%20al.pd

Hérnandez-Muñoz, P., Almenar, E., Ocio, M. J., \& Gavara, R. (2006). Effect of calcium dips and chitosan coating on postharvest life of strawberries (Fragaria x ananassa). Postharvest Biology Technology, 39(3), $247-253$. http://dx.doi.org/10.1016/j.postharvbio.2005.11.006

Hidalgo, M., Sánchez-Moreno, C., \& Pascual-Teresa, S. (2010). Flavonoid-flavonoid interaction and its effect on their antioxidant activity. Food Chemistry, 691-696. http://dx.doi.org/10.1016/j.foodchem.2009.12.097

Honarbakhsh, S., \& Schachter, M. W. (2009). Vitamins and cardiovascular disease. British Journal Nutrition, 101, 1113-1131. http://dx.doi.org/10.1001/jama.2012.14805

Korać, R. R., \& Khambholja, K. M. (2011). Potential of herbs in skin protection from ultraviolet radiation. Pharmacognosy Reviews, 5(10), 164-173. http://dx.doi.org/10.4103/0973-7847.91114

Kosińska, A., Karamác, M., Estrella, I., Hernández, T., Bartolomé, B., \& Dykes, G. A. (2012). Phenolic compound profiles and antioxidant capacity of Persea americana Mill. Peels and seeds of two varieties. Journal Agricultural Food Chemistry, 60(18), 4613-4619. http://dx.doi.org/10.1021/jf300090p

Lin, J. Y., \& Tang, C. Y. (2007). Determination of total phenolic and flavonoid contents in selected fruits and vegetables, as well as their stimulatory effects on mouse splenocyte proliferation. Food Chemistry, 101, 140 147. http://dx.doi.org/10.1016/j.foodchem.2006.01.014

Lu, Q., Arteaga, J. R., Zhang, Q., Huerta, S., Go, V. L., \& Heber, D. (2005). Inhibition of prostate cancer cell growth by an avocado extract: role of lipid-soluble bioactive substances. Journal Nutrition Biochemistry, 16(1), 23-30. http://dx.doi.org/10.1016/j.jnutbio.2004.08.003

Lu, Q., Zhang, Y., Wang, Y., Lee, R. P., Gao, K., Byrns, R., \& Heber, D. (2009). California Hass avocado: profiling of carotenoids, tocopherol, fatty acid, and fat contet during maturation and from different growing areas. Journal Agricultural Food Chemistry, 57(21), 10408-10413. http://dx.doi.org/10.1021/jf901839h

Mahattanatawee, K., Manthey, J., Luzio, G., Talcott, S., Goodner, K., \& Baldwin, E. (2006). Total antioxidant activity and fiber content of select Florida-grown tropical fruits. Journal Agricultural Food Chemistry, 54(19), 7355-7363. http://dx.doi.org/10.1021/jf060566s

Marinova, D., Ribarova, F., \& Atanassova, M. (2005). Total phenolics and total flavonoids in Bulgarian fruits and vegetables. Journal Chemistry Technology Metallurgy, 40(3), 255-260. Retrived from http://www.uctm.edu/journal/j2005-3/Marinova.pdf

Middleton, E. Jr., Kandaswami, C., \& Theoharides, T. C. (2000). The effects of plant flavonoids on mammalian cells: implications for inflammation, heart disease, and cancer. Pharmacological Reviews, 52, 673-751.Retrived from http://www._pharmrev.aspetjournals.org/content/52/4/673.full

Nayak, B. S., Raju, S. S., \& Chalapathi-Rao, A. V. (2008). Wound healing activity of Persea americana (avocado) fruit: a preclinical study on rats. Journal Wound Care, 17(3), 123-126. http://dx.doi.org/10.1155/2013/472382

Olaeta, J. A., Undurraga, P., \& Espinosa, G. (2007). Evolución del contenido de aceite y compuestos no saponificables en paltas (Persea americana Mill.) CVS. Hass, Fuerte e Isabel. Actas VI Congreso Mundial del Aguacate; 12-16. Retrived from http://www.avocadosource.com/WAC6/es/.../4b-183.pdf 
Omar, A. F., Atan, H., \& MatJafri, M. Z. (2012). NIR Spectroscopic properties of aqueous acids solutions. Molecules, 17, 7440-7450. http://dx.doi.org/10.3390/molecules 17067440

Pahua-Ramos, M. E., Ortiz-Moreno, A., Chamorro-Cevallos, G., Hernández-Navarro, M. D., Garduño-Siciliano, L., Necoechea-Mondragón, H., \& Hernández-Ortega, M. (2012). Hypolipidemic effect of avocado (Persea americana Mill) seed in a hypercholesterolemic mouse model. Plant Foods Human Nutrition, 67, $10-16$. http://dx.doi.org/10.1007/s11130-012-0280-6

Pandey, K. B., \& Rizvi, S. I. (2009). Current understanding of dietary polyphenols and their role in health and disease. Current Nutrition Food Science, 5, 249-263. Retrived from http://www.benthamscience.com/cnf/...4/D0004NF.pdf

Raharjo, S. H. T., Gomez-Lim, W. M. A., Padilla, G., \& Litz, R. E. (2008). Recovery of avocado (Persea americana Mill.) plants transformed with the antifungal plant defensin gene PDF12. In vitro Cellular Developmental Biology, 44(4), 254-262. http://dx.doi.org/10.1007/s11627-008-9117-2

Rodríguez-Carpena, J., Morcuende, D., Andrade, M. J., Kylli, P., \& Estévez, M. (2011). Avocado (Persea americana Mill.) Phenolics, in vitro antioxidante and antimicrobial activities, and inhibition of lipid and protein oxidation in porcine patties. Journal Agricultural Food Chemistry, 59(10), 5625-5635. http://dx.doi.org/10.1021/jf1048832

Salgado, J. M., Danielli, F., Regitano-D’arce, M. A. B.; Frias, A., \& Mansi, D. N. (2008). The avocado oil (Persea americana Mill) as a raw material for the food industry. Ciência Tecnologia Alimentar, 28, 20-26. http://dx.doi.org/10.1590/S0101-20612008000500004

Sanjust, E., Mocci, G., Zucca, P., \& Rescigno, A. (2008). Mediterranean shrubs as potential antioxidant sources. Natural Products Research, 22(8), 689-708. http://dx.doi.org/10.1080/14786410801997125

Sulaiman, S. F., Sajak, A. A. B., Supriatno, K. L. O., \& Seow, E. M. (2011). Effect of solvents in extracting polyphenols and antioxidants of selected raw vegetables. Journal Food Composition Analysis, 24, 506-515. http://dx.doi.org/10.1016/j.jfca.2011.01.020

Tango, J. S., Carvalho, C. R., \& Limonta, S. N. B. (2004). Caracterização física e química de frutos de abacate visando a seu potencial para extração de óleo. Brazilian Magazine Fruit Culture, 26(1), 17-23. Retrived from http://www.scielo.br/pdf/rbf/v26n1/a07v26n1

USDA (United States Department of Agriculture). (2011). Fresh California Avocados. Retrieved from http://fnic.nal.usda.gov/food-composition/food-fyi/avocado

Vinha, A. F., Barreira, S. V. P., Castro, A., Costa, A., \& Oliveira, M. B. P. P. (2013). Influence of the storage conditions on the physicochemical properties, antioxidant activity and microbial flora of different tomato (Lycopersicon esculentum L.) cultivars. Journal Agricultural Science, 5(2), 118-128. http://dx.doi.org/10.5539/jas.v5n2p118

Vinha, A. F., Soares, M. O., Herdeiro, T., \& Machado, M. (2012). Chemical composition and antioxidant activity of Portuguese diospyrus kaki fruit by geographical origins. Journal Agricultural Science, 4(2), 281-289. http://dx.doi.org/10.5539/jas.v4n2p281

Wang, W., Bostic, T. R., \& Gu, L. (2010). Antioxidant capacities procyanidins and pigments in avocados of different strains and cultivars. Food Chemistry, 122, http://dx.doi.org/10.1016/j.foodchem.2010.03.114

Yasir, M., Das, S., \& Kharya, M. D. (2010). The phytochemical and pharmacological profile of Persea americana Mill.. Pharmacognosy Reviews, 4(7), 77-84. http://dx.doi.org/10.4103/0973-7847.65332

Zieliski, H., \& Kozowska, H. (2000). Antioxidant activity and total phenolics in selected cereal grains and their different morphological fractions. Journal Agricultural Food Chemistry, 48, 2008-2016. http://dx.doi.org/10.1021/jf990619o

\section{Copyrights}

Copyright for this article is retained by the author(s), with first publication rights granted to the journal.

This is an open-access article distributed under the terms and conditions of the Creative Commons Attribution license (http://creativecommons.org/licenses/by/3.0/). 